Árpád Mibály

\title{
'I too have the right to be shown impossible' Re-reading the Beckett Trilogy
}

I'm the clerk, I'm the scribe, at the hearings of what cause I know not.

Texts for Nothing, No. 5

The thing to avoid, I don't know why, is the spirit of system.

The Unnamable

'Baldrick, have you no idea what irony is?'

'Yeah, ... it's like goldy and bronzy, only it's made of iron.'

Blackadder III

\section{I. 'I SEEM TO SPEAK, IT IS NOT I, ABOUT ME, IT IS NOT ABOUT ME.'}

This re-reading of the Trilogy will be carried out in search of a presence. This will be detective work of a sort where I will be satisfied with finding the clues and will refrain from arresting the felon. After all, this case may be of a nature more diabolical than criminal.

The sought presence is in want of a space to be present in, and I suggest that the Beckett Trilogy seeks to satisfy the desire of this presence while conscious of its impossibility. Less obscurely: something/someone outside the text seeks, and is refused, admission to it. More tactfully: the text seems to encourage/admit 
a reading that will see it as the attempts of a silent presence at claiming our attention.

This presence is the one that makes the narrator speak and provides a world for the narrator to speak of. One reason for my reluctance to call 'it' the name 'it' has earned in critical tradition is the confusion that surrounds this name.

Wayne Booth's 'implied author' had practical purposes at the time of its introduction: to relieve flesh-and-blood authors from accusations of immorality, when different works of the same writer seemed to suggest different authorial moral standpoints. The concept has gained wide currency ${ }^{1}$ even though the definition was not unequivocal. ${ }^{2}$ The most controversial issue is bow the implied author manifests itself. Booth sees no difficulty here:

These differences [between the implied authors of different works of the same author] are most evident when the second self is given an overt, speaking role in the story. When Fielding comments, he gives us explicit evidence of a modifying process [of the author's persona] from work to work...

(Booth, pp. 71-2; my emphasis)

Later he partly qualifies his statement by saying:

It is a curious fact that we have no terms either for this created 'second self' or for our relationship with him. None of our terms for various aspects of the narrator is quite accurate. 'Persona,' 'mask,' and 'narrator' are sometimes used, but they more commonly refer to the speaker in the work who is after all only one of the elements created by the implied author and who may be separated from him by large ironies. 'Narrator' is usually taken to mean the 'I' of the work, but the 'I' is seldom if ever identical with the implied image of the artist.

(Booth, p. 73)

A consistent application of this idea will lead us to the realisation that ' $\mathrm{T}$ ' is never identical with the implied author, that is, the implied author can never speak out directly. 'I' is reserved for the use of narrators, or, as William Nelles puts it, 'the

${ }^{1}$ For a review and critique, see William Nelles's 'Historical and Implied Authors and Readers.'

${ }^{2}$ In the first, 1961, edition of The Rhetoric of Fiction; the definition which set in motion much of Iser's work on the 'implied reader.' The second, 1980, edition does not seem to solve the contradictions of the first one. For this, see Nelles. 
historical author writes, the implied author means, the narrator speaks' (Nelles, p. 42).

Much attention is devoted to the problem in Uri Margolin's ambitious and rigorous 'alternative narratology':

The author of any FPN [first person narrative], be it fictional or factual, must use the 'I' expression to designate its textual speaker. In the case of a fictional narrative, the ' $\mathrm{I}$ ' expression occurring in any of the propositions contained in it is neither speaker indicator nor a referring expression with regard to the author of the text. Yet, paradoxically, the author of a fictional FPN can exist or be himself as the author of a FPN only if he employs the ' $\mathrm{I}$ ' expression without self-indication or selfreference, that is, only in so far as he assumes the role of the imputer who stands behind a not-I discourse... On the other hand, the author has no other expression but 'I' at his disposal on all those occasions when he wants to self-refer and self-indicate linguistically. Real creator and fictional creation are thus inevitably designated by one and the same expression. Once we know that a person is a writer of fictional FPN, each and every usage of the 'I' term by him becomes suspect, ambiguous, potentially undecidable, as it may designate the author and/or his double - the textual speaker, the person and/or the persona.

(Margolin, p. 205)

Both Booth and Margolin seem to comply with the traditional complacency that agrees to identify certain "II" terms' with the physical author (not to mention his implied double). What with language being a system of agreements, I may appear to be splitting hair when I insist the sweaty individual, as well as his dummy, be bereft of pronouns. 'I' I do not find suspect or ambiguous as regards authors, since it is not at their disposal at all to self-refer linguistically. Nothing is, that is. If the reference of ' $\mathrm{I}$ ' is ascertained in the (speech-)situation, the narrative situation defines the user of 'I' as narrator. And vice versa: it is exactly the "I" term' that defines or constitutes the narrator's position: if one uses 'I' in a text to refer to oneself one is a narrator. ${ }^{3}$ Not only does the non-identity of author and narrator facilitate such narrative tricks as the unreliable narrator (c.f. Booth's reference to the irony separating speakers and [implied] authors), it should also forbid the reader to make that identification. Is it the death of the (implied) author then?

\footnotetext{
${ }^{3}$ Meaning of course the use of 'I' outside inverted commas, i.e. non-reported discourse.
} 
Perhaps not. What is in his (their) power as far as self-reference goes is rhetoric. Though I will concentrate on irony, I suspect that most, if not all, figurative use of language may help an author(-figure) to span the void between ' $\mathrm{I}$ ' and him. Irony, understood as the conflict of intended (surface) and circumstantial meaning, is perhaps the most powerful tool in this respect. Consider but the case of the unreliable narrator: it is the ironic conflict of what he says and what it means in the given circumstances that posits, or calls the reader's attention to, the existence of someone 'smarter.' Someone, who not only knows more but is willing to let us see it. ${ }^{4}$

The problem with irony lies exactly in the role of intention: in its classic definition, the recognition of irony means the recognition of an ironic intention (c.f. e.g. Richter, p. 136). One aspect of Nelles's definition of the implied author he who 'consciously created and intended every implication, subtlety, ambiguity and complexity that can be discovered in the text' (Nelles, p. 26) - will in fact give strong support to this idea, as it ties all intentions to the implied author. The reader's task seems to consist of the recognition of these intentions - the implied reader's task, that is:

The implied reader would function only to receive without addition or subtraction, without physical, psychological, or cultural "interference with contact," the complete intention of the implied author (which is not necessarily the same as that of the historical author) and to understand the full meaning of the text.

(Nelles, p. 32)

Since Iser the implied reader has been understood as a role offered by the text to the real reader (Iser 1978, p. 35). However, W. Daniel Wilson criticised Iser's scheme for not offering enough 'playground' to the real reader to perform this role:

The implied reader is part of the overall textual meaning and is not to be confused with the real reader, ... who actualises the meaning and who correspondingly relates to the implied reader's role.

(Wilson, p. 851; my italics)

\footnotetext{
${ }^{4}$ If only by letting others speak about the same state of affairs. But that seems rather uncomplicated as (implied) author has his own recognizable role of compiler or editor, at least.
} 
This role seems to include the realisation of the text's ironic intentions, which realisation need be accepted/recognised by the real reader for irony to work upon him.

Now, if irony is understood as the tension of intention and circumstance, and all intentions in the text belong to the implied author, all irony must belong to him and him alone. Ergo, irony is a means for the implied author to talk about himself, or at least to call attention to himself.

\section{Or is it?}

While juggling with these terms and definitions, our poor real reader has been allotted a rather inferior role: to recognise roles and intentions and (oh, all right) to relate to them. But what if, as I believe, he already creates these roles etc. for himself to play with? Not out of the blue of course, but by using textual possibilities, adding his imagination, education or blindness. What if these textual doubles of real authors and readers, as far as the real reader is concerned, are not so much implied as inferred? (I borrow the term from Gérard Genette [mentioned and ignored in Nelles, p. 22], not being quite certain whether it contains more than the customary definition of the implied author/reader.)

Inferred will certainly be the author figure that irony allows to appear, irony being as much the real reader's projection as the text's offer. My readerly intention is ironic when I decide that these texts will be read as if they were not primarily about their admitted hero-narrators but about their author(s). (Who knows, the title of the last volume may refer not to the narrator but an authorfigure.) I 'actualise the meaning' (c.f. Wilson above) ironically by bringing those segments of the meaning-complex into play that are in tension with one another or the most apparent intention: that of an autobiography. This seems to be encouraged by the apparent play on the idea of autobiography itself in the whole rrilogy, writing pursued into the infinite density of now: Molloy and Nives write until the moment of writing, Malone tries to make writing acciripany him on the way out of existence, and the last narrator ${ }^{5}$ tries to write himself out of existence. Yes, it is the trilogy as a whole that encourages (not enables!) an ironic pursuit of its inferred author(s). Who will be referred to as IA, thus allowing for some nostalgia for the implied author.

\footnotetext{
${ }^{5}$ Provided there is only one. See below.
} 
II. 'BUT IT'S ENTIRELY A MATTER OF VOICES, NO OTHER METAPHOR IS APPROPRIATE.'

Any work of art will refuse to be reduced to any single meaning. An ironycentred reading seems to provide some unity to the various meanings the Beckett Trilogy offers. For instance, St. John Butler's reading in the light of Heidegger's Being and Time is illuminating enough and seems to tackle such puzzling problems as those of 'they,' 'the voices' and the longing for silence in The Unnamable. Yet, an important characteristic of the position of the narrators in the Trilogy, their consciousness of being authors and their awareness of being engaged in the writing of narratives, remains unapproached. Reading the Trilogy as a series of quests for IAs not only addresses this problem but accommodates a crux for long identified as central to the work, the mystery of the self. A mystery or an illusion? Whichever our preference, we will not be dissatisfied: the status of IA will cater for both tastes.

J. Hillis Miller finds the (realist) novel to (have) fulfil(led) a particular role in the maintenance of a (quaintly metaphysical) idea of the self:

... the novel, as the perpetual tying and untying of the knot of selfhood works, in the psychic economy of the individual and of the community, to affirm the fiction of character by putting it fictionally in question and thus short-circuits a doubt that, left free to act in the real social world, might destroy both self and community. Belief in the subject, in character, is precariously maintained by the novel over the abyss of its dismantling. ... The novel demonstrates, in a 'safe' realm where nothing serious is at stake, the possibility of maintaining the fiction of selfhood in the teeth of a recognition that selfhood is a fictive projection, an 'interpretation' not a fact, and is always open to being dissolved by a contrary interpretation - for example, that of the multiplicity or the nonentity of the ego.

(Miller, p. 213)

For believers of the ego the Trilogy, a work which constantly teases and dismantles the idea of a unified self (or any work for that matter), will offer the complete, though silent, self of IA: an insubstantial core that is doomed to manifest itself in delusive others yet strives to be recognised in its manifestations and offers those ironic possibilities for the reader to construe him. Advocates of the self as a metaphor for the intersection of discourses (a fiction) will recognise IA 
as one such creature: a curious, textless, fiction, which needs the reader's active help to be assembled.

\section{III. 'HOW LITTLE ONE IS AT ONE WITH ONESELF, GOOD GOD.'}

If irony is the means by which IA finds relief from silence then the three novels appear to invite/admit a search for different kinds of irony.

26

In Molloy comic excess raises the reader's awareness and invites/allows him to seek for the source of the oddity of the text beyond the narrators.

The work is built around the quest metaphor: the quest for a mother, for Molloy, for a self. Moran's rambling seems to accentuate this; his looking for Molloy and the parallel disintegration of his bourgeois identity help us equate his search with one for a self. Both Molloy's and Moran's quests are reenacted in writing, by means of constructing narratives, autobiographies. However, both autobiographers admit to be fictionalising: 'What I need now is stories,' says Molloy at the beginning of his narrative (M1, p. 14) ${ }^{6}$ and later he talks about the period of his life being related as 'the one I am trying to patch together here' (M1, p. 70). Moran early on meets the possibility of Molloy's (together with earlier Beckett heroes') being a fiction of his own:

Oh the stories I could tell you if I were easy. What a rabble in my head, what a gallery of moribunds. Murphy, Watt, Yerk, Mercier and all the others. I would never have believed that - yes, I believe it willingly. Stories, stories. I have not been able to tell them. I shall not be able to tell this one.

(M2, p. 126)

Thus the quest metaphor is soon associated with problems of authorship, more particularly with that of authorial identity, which will come to dominance in the later parts of the Trilogy, especially in The Unnamable. If the present narrative quest is unsuccessful as far as the goal is concerned, the project appears nevertheless accomplished with the circle neatly closing at the starting point. Actually, only in Molloy's case: Moran's last words not only admit his having

\footnotetext{
${ }^{6}$ I shall use the following abbreviations for the novels of the Trilogy: M1 and M2 for part one and two of Molloy, respectively; $M D$ for Malone Dies; $U$ for The Unnamable.
} 
been writing fiction but also uproot the narrative situation and thus the narrator's position: 'Then I went back into the house and wrote, It is midnight. The rain is beating on the windows. It was not midnight. It was not raining' (M2, p. 162).

But let us first treat what I meant by the 'oddity' of the text. Molloy claims that 'I know that I know nothing' (M1, p. 25) but never ceases to comment on events or motives, seemingly only to reinforce the statement. However, his uncertainty or ignorance appears to be simulated: he often gives way to remarks of sound logic, which he hastens to shroud in a mist of doubt:

They paid no attention to me and I repaid the compliment. Then how could I know they were paying no attention to me, and how could I repay the compliment, since they were paying no attention to me? I don't know. I knew it and I did it, that's all I know.

(M1, p. 23)

Similarly, his despair often seems affected: 'But I have no reason to be gladdened by the sun and I take good care not to be' (M1, p. 29). He is brandishing his crippled state as if to appeal for compassion or, at least, attention.

But I was used to seeing the sun rise in the south, used to not knowing where I was going, what I was leaving, what was going with me, all things turning and twisting confusedly about me. It is difficult, is it not, to go to one's mother with things in such a state...

$$
\text { (M1, p. 42; my italics) }
$$

This is sharply contrasted with the ease, wit and occasional sombre beauty of his prose. He seems to take real pride in writing it:

And even my sense of identity was wrapped in namelessness often hard to penetrate, as we have just seen I think.

$$
\text { (M1, p. 30) }
$$

And though it is not part of my tottering intentions to treat here in full, as they deserve, these brief moments of the immemorial expiation, I shall nevertheless deal with them briefly, out of the goodness of my heart, so that my story, so clear till now, may not end in darkness...

$$
\text { (M1, p. 72) }
$$


This latter example already displays Molloy the ironist, who, though not finding a better way of self-exploration than the narrative, is fully aware of its limitations:

Yes, even then, when already all was fading, waves and particles, there could be no things but nameless things, no names but thingless names. I say that now, but after all what do I know now about then, now when the icy words hail down upon me, the icy meanings, and the world dies too, foully named. All I know is what the words know, and the dead things, and that makes a handsome little sum, with a beginning, a middle and an end as in the well-built phrase and the long sonata of the dead. And truly it little matters what I say, this or that or any other thing. Saying is inventing. Wrong, very wrong. You invent nothing, you think you are inventing, you think you are escaping, and all you do is stammer out your lesson, the remnants of a pensum one day got by heart and long forgotten, life without tears, as it is wept.

(M1, pp. 30-1; my italics)

'To hell with it anyway,' he closes these ponderings, and he goes on affecting the 'incurious seeker' (M1, p. 59) for fifty more pages.

We might, like Steven Rosen, want to take these statements at face value and place Beckett's narrators in a tradition, that of pessimistic sages. However, if we take heed of Molloy's ironic attitude towards his endeavour, we might follow suit and probe, in our turn, into the structure and motifs of his narrative to find whether they can be of the same origin, that is, whether they lie within the realm of one and the same hero-narrator. This we might want to do even if we agree with Iain Wright that despite Molloy's doubts and deconstructive activity the 'secure narrative subject-positions' [i.e., the position of author and character] in his narrative remain intact (Wright, p. 22).

One such prominent discrepancy is the one between the various mythic and epic reincarnations of the quest metaphor that the narrators narrate themselves into. Rubin Rabinovitz provides a whole catalogue of allusions to the Bible, the Odyssey and The Divine Comedy, to mention only three texts the novel makes extensive use of.

[Molloy and Moran] appear in various guises when they play different parts in the quest metaphor: exiles, fabulous voyagers, explorers of the 
underworld, religious pilgrims, or mental travellers. To underlie these roles, Beckett alludes to the various epic heroes who typify them.

(Rabinovitz, p. 44)

The roles often contradict one another, creating disunities the reader is hard put to settle.

This is the humour of reversals and unfulfilled expectations, a way of mocking the inflated claims epic authors sometimes make for their heroes. Beckett's irony transforms his own heroes into more human creatures of ordinary proportions lest they be overwhelmed by an aura of epic hyperbole.

(Rabinovitz, p. 41)

This seems credible - just as much as its opposite: the ambiguities may prompt the reader to look upon the heroes as less human, that is, more creature-like. Which, in turn, will set the reader upon looking for the creator. The quest, then, appears to be doubled on a different plane, with the reader in search of the source of the inconsistencies, i.e., a unifying meaning.

Such an attempt is encouraged by Moran alluding to, and then Malone claiming, authorship of Molloy's text. In fact, the function of the Moran narrative may be more readily anchored to another cause: the reinforcement of the main theme of the first part, the search for self through narration. This is carried out by reiterating scenes or even passages in the two narratives (or four, as this seems to apply to the other two, as well). Rabinovitz finds such repetition to be carrying underlying meanings common to both (or all four) texts:

Beckett uses these parallel scenes to hint that the trilogy's protagonists can in subtle ways be linked to one another, that their descriptions of certain temporal adventures can be interpreted as imperfect representations of subtle mental experiences that they have in common.

(Rabinovitz, p. 72)

Again, readers of an ironic orientation may want to see these common scenes as invitations to a search for a common origin. As a matter of fact, Rabinovitz himself may also hint at this aspect of the incongruities, when he says of the recurring motif of the bicycle: 'Here, as elsewhere in 
the trilogy, the similarities serve to encourage inquiries rather than to terminate them prematurely'

(Rabinovitz, p. 84)

Iser also contributes to the discussions on the problem of contradictions in the Trilogy. He uses a concept of Sartre, negativity, which is the network of denials in a text, a system of obscurities that invite the reader to discover what the work suppresses (Iser 1989, p.140).

[W] hat the reader has to find can be taken to be the opposite of what has been negated, and so contrasts and contradictions form a frame of reference within which the intention of negation can be discovered. ... However, when such frames of reference are dismantled or even deliberately suppressed, negation changes into negativity, and instead of a demand we have a suction effect.

(Iser 1989, p. 140)

In the Trilogy the epic allusions create such a fantastic web which cannot provide a comprehensive frame of reference, what is more, the contradictions invalidate the working of any chosen epic as frame. 'If a negation can no longer be viewed in terms of any given frame of reference, it explodes into a multiplicity of possibilities' (Iser 1989, p.141). Iser also thinks that this richness prompts the reader to look for a common source. He quotes Merleau-Ponty, who has this to say on the medium of visual arts: 'it is peculiar to the visible ... that it is duplicated by something invisible which is, to a certain extent, absent and which the visible makes present' (quoted in Iser 1989, p. 141). Iser sees Beckett's prose as a peculiar medium calling attention to, or rather, prompting the reader to start searching for, its origin.

[O]ur own imaginations are concerned not with concretising the deformations of the characters or their constant failures so much as with the duplication of the 'invisible,' for the concretising of deformations and failures can only come about if we can discover their cause, and this is never given to us. We are compelled to try to fulfil a hidden potential, as we seek to conceive the conditions that alone can lead us to the sense of what we are reading.

(Iser 1989, p. 142) 
Iser seems to mean that the actual absence of the physical deformations of the characters calls attention to the medium that allows for their virtual presence.

It is Moran who first sounds the new note of doubt concerning not simply the success but the rationale of the endeavour, a note that will claim supremacy in the ensuing volumes. Reminiscing about a Molloy he has probably never seen, he says:

But images of this kind the will cannot revive without doing them violence. Much of what they had it takes away, much they never had it foists upon them. And the Molloy I brought to light, that memorable August Sunday, was certainly not the true denizen of my dark places, for it was not his hour. But so far as the essential features were concerned, I was easy in my mind, the likeness was there.

(M2, p. 105)

This, as yet, is only the familiar tone of scepticism towards representation. But he goes on to add:

And the discrepancy could have been still greater for all I cared. For what I was doing I was doing neither for Molloy, who mattered nothing to me, nor for myself, of whom I despaired, but on behalf of a cause which, while having need of us to be accomplished, was in its essence anonymous, and would subsist, haunting the minds of men, when its miserable artisans should be no more.

(M2, p. 105; my italics)

'What I was doing': simply the search? Or rather the reminiscing, i.e. cladding 'the true denizen of my dark places' in words and thus bringing him 'to light'? And does 'us,' the agents of the 'cause,' refer only to Moran and Molloy? $c$ narrator and his narratee? All narrators and narratees? What if the causc is speaking, naming or narrating? This conjecture is also made possible by Moran's hint at 'artisans' and a synonym two lines later: 'It will not be said, I think, that I did not take my work to heart. But rather, tenderly, Ah those old craftsmen, their race is extinct and the mould broken' (M2, p. 105). 


\title{
IV. 'I CAN SAYNOTHING THAT IS NOT TRUE.'
}

If it is agreed that the cause is story-telling, Malone Dies takes up the hammer to break the mould. The irony here seems to operate with the blatant foregrounding of the act of narration, of creation.

Wright thinks that in this Malone differs from Moran only in the intensity of his practice: he seems to have 'nothing to do but repeat and extend the deadlock into which his two predecessors have narrated themselves' (Wright, p. 24). However, they may differ not merely in the fervour with which they seek the self through narration: Malone takes the decisive step of equating his life with the text. The statement - '[ $t]$ his exercise book is my life, this big child's exercise book, it has taken me a long time to resign myself to that' ( $M D$, p. 252$)$ - is prepared in many ways throughout his narrative. After giving his program ('I am going to play') he relates 'my old aporetics' of whether he can go on writing till the end, whether he can fill his time with narrative ( $M D$, p. 166). But there are two episodes that show how narrative is his time, how only the narrative is time: it is only when relating the loss of his exercise book and then of his pencil that the time spent unwriting appears. Another 'quibble' that gains ironic overtones with the admission of his book being his life is whether he has lived at all.

\begin{abstract}
And gravely I struggled to be grave no more, to live, to invent, I know what I mean. But at each fresh attempt I lost my head, fled to my shadows as to sanctuary, to his lap who can neither live nor suffer the sight of others living. I say living without knowing what it is. I tried to live without knowing what I was trying. Perhaps I was living after all, without knowing. I wonder why I speak of all this. Ah yes, to relieve the tedium. Live and cause to live.
\end{abstract}

$(M D$, p. 179)

His narrative of course is a series of examples of 'causing to live.' His 'shadows' illustrate what it is to be invented and made to live. This creates an awareness in the reader so that the better to appreciate it when he is revealed to be one who 'can neither live nor suffer the sight of others living':

I fear I must have fallen asleep again. In vain I grope, I cannot find my exercise book. But I still have the pencil in my hand. I shall have to wait for the day to break. God knows what am I going to do till then.

I have just written, I fear I must have fallen, etc. I hope this is 
not too great distortion of the truth. I now add these few lines before I depart from myself again.

$$
\text { (MD, p. 191; my italics) }
$$

His apology reinforces and calls attention to the oddity of the previous paragraph. If it was written and is part of the text in the exercise book, and moreover Malone claims himself unable to have committed it, then somebody else had to do it. This is not a problem to reason about (with, say, the introduction of a super-narrator): it is there for the reader to doubt.

The IA of Malone Dies also claims our attention by the views Malone expresses on the nature of fictional language.

His starting position, though far from a firm belief in straightforward connotation, and thus in the difference between signified and signifier, will still admit the possibility. 'There is no use indicating words, they are no shoddier than what they peddle' (MD, p. 179). What they peddle is of course his life, and he pays dearly for his naiveté, since all he can say some thirty pages later is: 'It's vague, life and death' (MD, p. 206). Four pages later he is being ironic at the expense of the notion of soul - an irony we in our turn can apply to him:

And it is a pleasure to find oneself again in the presence of one of those immutable relations between harmoniously perishing terms and the effect of which is this, that when weary to death one is almost resigned to - I was going to say the immortality of the soul, but I don't see the connexion.

$(M D$, p. 210)

Six pages elapse, and he seems to have wised up:

But I tell myself so many things, what truth is there in all this babble? I don't know. I simply believe I can say nothing that is not true, I mean that has not happened, it's not the same thing but no matter. Yes, that's what I like about me, at least one of the things, that I can say, Up the Republic! for example, or, Sweetheart! for example, without having to wonder if I should not rather have cut my tongue out, or said something else.

$(M D$, p. 216) 
'[I]t's not the same thing' but of course this said by such a superb ironist as Malone will make us wonder. Still later on, he inadvertently admits that his existence is tied to language, when talking about his chamber-pot he remarks: 'They are not mine, but I say my pots, as I say my bed, my window, as I say me' (MD, pp. 232-3).

It is his 'death,' long awaited, that is his final comment on the power of language in world-creation, a comment which, ironically, is not uttered by him. His narrative ends not on the metafictional level but while Macmann and Co.'s outing from the asylum is being related.

We are invited (by the novel's title, if nothing else) to construe this as a sign of the author's (Malone's) death in medias res, so to speak; nevertheless, an ambiguity lingers over this ending, leaving us to wonder, which was the 'more real,' the world in which Malone lives and (presumably) dies, or the world which he has projected, and within which the text ends.

(McHale, p.12)

Or perhaps the one in which Malone's world and narrative were written?

\section{V. 'WHERE I AM THERE IS NO ONE BUT ME, WHO AM NOT.'}

With such predecessors, The Unnamable has to use especially forceful irony to hint at its IA. Its narrator knows how shoddy words are and tries to dismantle language in search of a place for the self - or to show how fictional the self is.

The narrator startles us with how his narrative begins: 'Where now? Who now? When now? Unquestioning. I, say I' $(U$, p. 267). His first sentences seem to question, if not eradicate, the three basic components of a (fictional) situation that conventional narratives hasten to provide: person, place and time. 'I, say I' - like the M's, he declares himself both subject and narrator, but this curt sentence seems to be burdened with the awareness of how the subject is created. (Margolin's idea of this sentence [and the previous one?] as the author's reply or command in response to the textual speaker's question [Margolin, p. 206] is appealing but inapplicable, what with IA having no voice of his own.) He goes on to implore into the method: '.. how proceed? By aporia pure and simple? Or by affirmations and negations invalidated as soon as uttered, or sooner or later?' $(U$, p. 267). Malone's dabbling with creation and the nature of language, however, 
has already shown us that in fiction no statement can be invalidated: what has been said is there to stay, cannot be unsaid. Hence the desire for silence. The aporetic nature of the whole enterprise, that is, seeking for the self with a language that distracts attention from it, is also realised early on:

One starts speaking as if it were possible to stop at will. It is better so. The search for the means to put an end to things, an end to speech, is what enables the discourse to continue.

I hasten to add that a contrary reading, one which sees this text as an attempt to get rid of the old 'discourse' of the self, is also possible. Then the enterprise is a failure because language has its revenge by creating (or by inviting belief in) unwanted selves. This would explain the narrator's despair/rage over his creative forces. Again, the tension of the two readings is probably more valuable than a univocal meaning.

Perhaps it is time I paid a little attention to myself, for a change. I shall be reduced to it sooner or later. At first sight it seems impossible. Me, utter me in the same foul breath as my creatures? Say of me that I see this, feel that, fear, hope, know and do not know? Yes, I will say it, and of me alone.

$$
\text { (U, p. 275) }
$$

Speaking of himself alone is what seems impossible. He soon gets lost among his creatures, just like the reader when he tries to identify the voice speaking. Is it Mahood, the original speaker or perhaps Worm? It does not really matter: the less embodied, the more indefinable the voice is, the better it serves to express the basic predicament: language only obscures the object of the quest (be it self or selfless-ness). Variants of the clause 'it is only a matter of voices' appear at least six times in the text (e.g. $U$, pp. 298, 308, 317, 319, 354). Since the main themes are unfolded within thirty pages from the start (together with narrator's claim that it is not his voice speaking $[(U$, p. 281$])$ the whole text must be seen as a desperate attempt at getting behind the snare of language, at making it transparent: 'Bah, any old pronoun will do, provided one sees through it. Matter of habit' $(U$, p. 315). The ultimate goal is first named thus: 'Ah if I could only find a voice of my own, in all this babble, it would be the end of their troubles, and of mine' $(U$, p. 320$)$. By this point the speaker has already tried to define himself in the 
negative, as none of the M's or any other creatures ( $U$, pp. 299, 308). Should the reader have reached this narrative unaware of the blows the notion of referentiality has taken, several hints at how the text should or can be read are provided, if only indirectly, in the form of notes, outbursts or 'resolutions':

I might as well tell another of Mahood's stories and no more about it, to be understood in the way I was given to understand it, namely as being about me.

Well, if they ever succeed in getting me to give a voice to Worm, in a moment of euphory, perhaps I'll succeed in making it mine, in a moment of confusion. There we have the stake. But they won't. Did they ever get Mahood to speak? It seems to me not. I think Murphy spoke now and then, the others too perhaps, I don't remember, but it was clumsily done, you could see the ventriloquist.

$$
\text { (U, p. 320) }
$$

More resolutions. ... Assume notably henceforward that the thing said and the thing heard have a common source, resisting for this purpose the temptation to call in question the possibility of assuming anything. ... Set aside, once and for all, at the same time as the analogy with orthodox damnation, all idea of beginning and end. Overcome, that goes without saying, the fatal leaning towards expressiveness. Equate me without pity or scruple, with him who exists, somehow, no matter how, no finicking, with him whose story this had the brief ambition to be.

If this latter sounds like a plea of IA to the reader we must still not forget that what we can hear/read are never his words. If we seek him with irony then he escapes into paradox, for how else shall we characterise our language-based cognitive search for 'someone' resting in the 'unthinkable unspeakable' (U, p. 307)? 
... I am far, do you hear him, he says I'm far, as if I were he, no, as if I were not he, for he is not far, he is here, it is he who speaks, he says it's I, then he says it's not, I am far...

In such circumstances it is only natural that this susceptibility of language, this impotence to name unequivocally should appear diabolical:

....all here is sin, you don't know why, you don't know whose, you don't know against whom, someone says you; it's the fault of the pronouns, there is no name, for me, no pronoun for me, all the trouble comes from that...

Well, $I$ will be damned if I finish my essay with the compulsory recital of the famous last words 'I can't go on, I'll go on' ( $U$, p. 382). Especially because the supposed effect of the discourse rambling on in damnation for ever is undermined by that inconspicuous full stop. Oh, the discourse goes on all right but it is only in silence that there can be any speaking about ' $m e$ ' - or it is only silence that can unveil the self-creating trick of language.

... it's his turn again now, he who neither speaks nor listens, who has neither body nor soul, it's something else he has, he must have something, he must be somewhere, he is made of silence, there's a pretty analysis, he's in the silence, he's the one to be sought, the one to be, the one to be spoken of, the one to speak, but he can't speak, then I could stop, I'd be he, I'd be the silence, I'd be back in the silence, we'd be reunited, his story the story to be told, but he has no story, he hasn't been in story, it's not certain, he's in his own story, unimaginable, unspeakable, that doesn't matter, the attempt must be made, in the old stories incomprehensibly mine, to find his, it must be there somewhere, it must have been mine, before being his, I'll recognize it, the story of the silence that he never left ...

(U, p. 380)

*

A final remark: just how many IAs is the kind reader to consider? Has the Trilogy one and the same? Why is it not stated in so many words? Because this lies somewhat beyond my present interest, that is, showing how the text can (be made 
to) refer to its silent origin, without telling what this origin is in fact like. Though it is implicitly there, the actual quality of the IAs of the three parts of the Trilogy, and their possible likeness or identity, requires a more detailed analysis. Even what my first epigraph aims to suggest in the present circumstances is only a vague awareness of how the attempt of upholding the problem returns in Beckett's later prose. In fact, a similar reading of Texts for Notbing appears very illuminating - but has to await its turn. Silence now.

\section{REFERENCES}

Beckett, Samuel: The Beckett Trilogy: Molloy, Malone Dies, The Unnamable. London: Pan Books Ltd., 1987.

Booth, Wayne: The Rhetoric of Fiction. Chicago and London: University of Chicago Press, 1961.

Iser, Wolfgang: The Act of Reading: A theory of aesthetic response. Baltimore and London: J. Hopkins UP, 1978.

Iser, Wolfgang: "The Pattern of Negativity in Beckett's Prose" in: Prospecting: from Reader Response to Literary Anthropology. Baltimore and London: J. Hopkins UP, 1989.

Margolin, Uri: "Dispersing/Voiding the Subject: A narratological perspective." Texte 5/6, (1986), 181-210.

McHale, Brian: Postmodernist Fiction. New York: Methuen, 1987.

Miller, J. Hillis: "Rhetorical Study at the Present Time" in: Theory Now and Then. Durham: Duke UP, 1991.

Nelles, William: "Historical and Implied Authors and Readers." Comparative Literature, Winter 1993, 22-46.

Richter, David H.: “The Reader as Ironic Victim." Novel 14:2 (1981) 135-51.

Rosen, Steven J.: Samuel Beckett and the Pessimistic Traditior. New Brunswick: Rutgers UP, 1976.

Rabinovitz, Rubin: Innovation in Samuel Beckett's Fiction. Urbana and Chicago: U of Illinois P, 1992. 
St. John Butler, L.: Samuel Beckett and the Meaning of Being: a study in ontological parable. London: MacMillan, 1984.

Wilson, W. Daniel: 'Readers in the Text.' PMLA 96:5, (1981) 848-63.

Wright, Iain: “'What Matter Who's Speaking?” Beckett, the Authorial Subject and Contemporary Critical Theory.' Southern Review 16:1, (March 1983) 5-30. 